\title{
Socio-Economic Study of Tomato Producing Farmers in Lamahi, Dang
}

\author{
Kabita Basyal $^{1}$, Kapil Khanal ${ }^{2 *}$ and Sanjay Dhakal ${ }^{3}$ \\ ${ }^{1}$ Department of Entomology, Nepal \\ ${ }^{2}$ Department of Agricultural Economics, Nepal
}

${ }^{3}$ Agri-economist, Nepal

*Corresponding author: Kapil Khanal, Department of Agricultural Economics, Nepal

ARTICLE INFO

Received: 蔧 August 21, 2019

Published: 幽 August 27, 2019

Citation: Kabita Basyal, Kapil Khanal, Sanjay Dhakal. Socio-Economic Study of Tomato Producing Farmers in Lamahi, Dang. Biomed J Sci \& Tech Res 20(5)2019. BJSTR. MS.ID.003521.

Keywords: Farmers; Income; Market; Production; Tomato

\begin{abstract}
A study was conducted in 2017 for socioeconomic study of tomato producing farmers in Dang district of Nepal. Lamahi municipality was purposively selected for the study because of its potentiality on vegetable production. Altogether 60 households comprising 30 from ward no.3 and 30 from ward no. 4 of the area were selected by using simple random technique. Primary data was collected using interview schedule, direct observation, focus group discussion, key informant interview whereas secondary data was collected from various web reviews, publications and reports of different governmental as well as non-governmental agencies. Descriptive and analytical tools were used for the analysis of data. The study showed that the main source of income was agriculture in both wards. The major cost of production was found to be Labor cost. Financial analysis for sampled households revealed that BC ratio was 3.70. Likewise, most significant marketing channel was from i) producer to consumer ( $88.88 \%$ of respondents) followed by ii) from producer to wholesaler to consumer ( $11.67 \%$ of respondents). The findings of the study concluded that tomato production is a financially feasible enterprise and very significant in improving the socioeconomic condition of the farmers.
\end{abstract}

Abbreviations: APP: Agriculture Perspective Plan; DADO: District Agriculture Development Office; ASC: Agriculture Service Centre; SPSS: Statistical Package for Social Science

\section{Introduction}

Agriculture is the boon for Nepalese Economy. Around $65.6 \%$ of Nepalese people depend on agriculture for their livelihood MoAD [1]. This sector alone contributes about $29 \%$ of nation's GDP MoAD [1]. Among the horticulture crops, vegetable sector is emerging as an important sub sector and is contributing significantly to total horticultural GDP. Horticulture alone share 17\% of AGDP MoAD, [1]. The Agriculture Perspective Plan (APP) designated vegetable crops as one of the priority crops for Nepal's agriculture development. Different promotional campaign for the commercial production of vegetables has been initiated by government as well as private sector to increase the income of farmers and generation of employment opportunities at rural areas of the country resulting into significant increment of vegetable production. By realizing the importance and role of horticulture, the agriculture perspective plan (APP) targeted the growth rate of horticulture GDP in particular to 5.5 percent per annum by $2014 / 2015$ and the growth rate of vegetable GDP in particular to 5.42 percent per annum.

Among different vegetables like cauliflower, turnip, cabbage, potato, brinjal, carrot, tomatoes, chilli etc., tomato is one of the most commercially grown vegetable in Nepal. Tomato (Lycopersicum esculentum) belongs to the family, Solanaceae. The average productivity of Tomato in Nepal during FY 2015/16 is 13996 $\mathrm{kg} / \mathrm{ha}$ Krishi dairy [2]. The development of vegetables in Nepal started during early forties Awasthi [3]. According to Singh [4] the most commonly grown areas of tomato in Nepal are Ishworpur (Sarlahi), Dhalkebar (Dhanusha), Panchakhal (Kavre), Namatar, Bajrabarahi and Handikhola (Makawanpur), Lamatar (Lalitpur), Hirapur (Mahottari), Harre (Surkhet). The main vegetables grown are cauliflower, cabbage, radish, tomato, broadleaf mustard, carrot, peas, beans, chili, okra, brinjal, onion, cucumber, pumpkin, bitter 
gourd, bottle gourd SINA [5]. Dang district is full of potential in agriculture. Cereal crop along with pulses, oilseed and horticultural crops are grown over here. Tomato is one of the famous horticultural commodities grown over here. The area, production and productivity under tomato in Dang was $1000 \mathrm{ha}, 15000 \mathrm{Mt}$, and $15 \mathrm{Mt} / \mathrm{h}$ a respectively SINA [5].

\section{Methodology}

Lamahi municipality of dang district being the potential area for vegetable production including tomato was purposively selected for the study of my research. The vegetable grower households of Lamahi municipality of Dang district were selected as the sample population for this research. The most active and commercial vegetable growing farmers were selected as the respondent by consulting the District Agriculture Development Office (DADO), Agriculture Service Centre (ASC), Agricultural Cooperatives and key informants. Out of many farmers, 60 were considered as the respondent in my study. Out of 60,30 respondent were selected from Lamahi municipality ward no 3 and other 30 respondent were selected from ward no 4 . The pre-tested interview schedule was administrated to the sampled farmers, traders and consumers for the collection of primary data.

These data were obtained through household survey, focus group discussion and key informant interview. The secondary information was obtained through reviewing different publication produced by Vegetable Development Directorate, Department of Agriculture, Ministry of Agriculture and Development (MoAD) and District Development Office (DADO) of Dang district. Single set of interview schedule was prepared for the collection of primary data. For the analysis of the study descriptive and analytical tools were used. Data entry and analysis was done by using computer software packages like the Statistical package for Social Science (SPSS), and Microsoft Excel. Basically, Cost of production, Total income from Tomato, Benefit cost ratio, and Marketing Channel were analyzed to study the economics of tomato production and marketing. The socio-demographic and farm characteristics were used for descriptive analysis of the study area and study population. Variables like name, sex, age, educational status, occupation, source of income and area under Tomato were analyzed descriptively and presented in frequencies, percentages, means and standard errors together with non-parameter test whenever applicable.

\section{Results and Discussion}

In total 60 farmers were considered for my study. They were selected from ward no 3 and 4 of Lamahi municipality. Among them the maximum age of respondent was found to be 74 and minimum age was found to be 19. In case of $\mathrm{HHH}$, the maximum age was found to be 74 and minimum age was found to be 30 . After my study in sampled area, farmers of ward no 4 were found to be more educated in comparison to ward no 3 . All the HHH were found to be male. In ward no $4,16.67 \% \mathrm{HHH}$ were found to be illiterate, $33.33 \%$ were able to read and write, $23.33 \%$ have been studied up to primary level, other $23.33 \%$ have been studied up to secondary level and only $3.33 \%$ have been studied up to higher secondary level. In ward no 3, 20\% HHH were found to be illiterate, $23.33 \%$ were able to read and write, $30 \% \mathrm{HHH}$ have been studied up to primary level, other $20 \%$ have been studied up to secondary level and $6.67 \% \mathrm{HHH}$ have been studied up to higher secondary level. The occupational pattern of the HHH provides the knowledge about the household income.

According to the result of study, it can be concluded that agriculture was major occupation in ward no 3 and business was major occupation in ward no 4 . In ward no $3,46.67 \%$ of sampled farmers were engaged in Agriculture, $43.33 \%$ were engaged in business, $6.67 \%$ were engaged in service and $3.33 \%$ in others. In ward no $4,46.67 \%$ of sampled farmers were engaged in agriculture, $50 \%$ were engaged in business and 3.33\% were engaged in service. Among 60 sampled farmers, the main source of income was found to be from agriculture in both wards followed by Private source, civil service, business, and remittance. The average land for tomato production in ward no 3 was found to be 2.35 kattha and in ward no 4 it is found to be 1.13 kattha. These two wards were found to be moderately different statistically in case of total area under tomato production. In the sampled area the highest cost was found to be in land preparation cost (including labor cost and machinery cost) followed by harvesting cost, plant protection cost, FYM cost, cost of seeds, irrigation cost and fertilizer cost. In case of FYM amount and irrigation the two wards were found to be highly different statistically.

The total production of tomato in ward no 3 and 4 was found to be 32.51 quintal per HHs and 14.67 quintal per HHs respectively. Among total production, 29.65 quintal in ward no 3 and 14.42 quintal in ward no was found to be sold respectively. The total income per HHs was found to be Rs 93296.67 and Rs 40715 in ward 3 and 4 respectively. The total cost was obtained by adding all the variable cost incurred during production. In ward no 3 the total cost was Rs 23149.70 and in ward no 4 it was Rs. 12021.30. The BC ratio in ward no 3 and 4 was found to be 4.03 and 3.38 per $\mathrm{HH}$ respectively. When the $\mathrm{BC}$ ratio is greater than 1 it is said to be accepted economically so the tomato production business seems to be accepted and profitable in both wards of the sampled area. 2.78 Benefit/Cost ratio of tomato production was found under the plastic tunnel indicating higher profit in this business Gautam et al. [6]. According to Shende and Meshram 2015, the benefit cost ratio for Tomato over the cost A2, B3, C1, C2 and C3 was obtained as 3.73, $1.94,2.67,1.85$ and 1.68 respectively. So, the tomato production is a profitable business $[7,8]$. The calculated $\mathrm{BC}$ ration has been shown below; In Lamahi municipality only two marketing channels were prevailing as the most common marketing channel. They are shown below;
a. Farmers to Consumer
b. Farmers to Wholesaler to Consumer 


\section{Conclusion}

The socio-economic condition of the tomato producing farmers in Lamahi municipality was found to be more than better. The study had found that the tomato production was economically beneficial and highly profitable with the high $\mathrm{BC}$ ratio in the study area. Despite some production and marketing problems the Tomato farming was found to be flourishing as sound business in the study area. The most common marketing channel in the study area was found to be;
a. Farmers and consumer
b. Farmers to Wholesaler to Consumer

\section{Acknowledgement}

I want to thank my supervisor Mr. Kapil Khanal and Mr. Sanjay Dhakal for their continuous encouragement, invaluable suggestion and critical comments for improving the quality of this study. Heartiest thanks owed to my friend Pratikshya Oil Chhetri and Sima Marasini for their support and help during my study. With most appreciation, I am thankful to all my respondents of Lamahi municipality for their valuable time and genuine information with great hospitality.

\section{ISSN: 2574-1241}

DOI: $10.26717 /$ BJSTR.2019.20.003521

Kapil Khanal. Biomed J Sci \& Tech Res

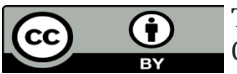

This work is licensed under Creative Commons Attribution 4.0 License

Submission Link: https://biomedres.us/submit-manuscript.php

\section{References}

1. (2015) MOAD, Statistical Information on Nepalese Agriculture, Singh Durbar, Kathmandu, Nepal.

2. Krishi Diary (2072) Ministry of Agriculture and Development. Department of Agriculture, Agriculture Information and Communication Centre, Harihar Bhawan, Lalitpur.

3. Awasthi BD (2007) Relevance of Market Information System to Environment Protection. The Journal of Agriculture and environment, Vol. 8. Ministry of Agriculture and Cooperatives, Kathmandu, Nepal.

4. Singh D (2010a) Tomato 'Srijana': Cultivating Technology. Vegetable Development Directorate, Lalitpur, Nepal.

5. (2016/17) SINA, Statistical Information on Nepalese Agriculture. Agribusiness Promotion and Statistics Division. Singh Durbar, Kathmandu, Nepal.

6. Gautam P, R Bhandari (2015) Benefit Cost Analysis of Tomato Cultivation under Plastic Tunnel Technology in Peri-Urban Areas of Kathmandu Valley.

7. APP (1995) Agriculture Perspective Plan. Agricultural Project Service Centre and John Mellor Associates, Inc. National Planning Commission, $\mathrm{HMG} / \mathrm{N}$ and $\mathrm{ADB} /$ manila.

8. Shende NV, RR Meshram (2015) Cost benefit analysis and marketing of tomato .American International Journal of Research in Formal, Applied \& Natural Sciences 11(1): 46-54.

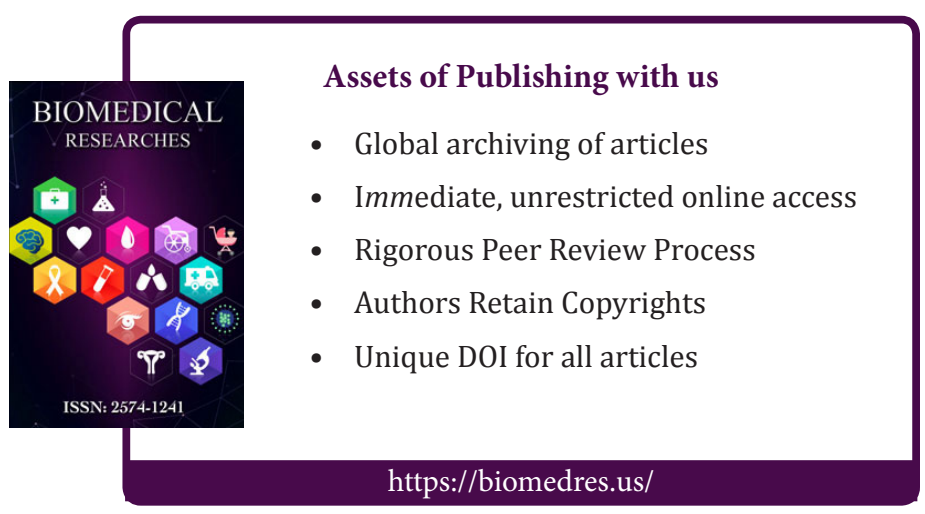

